\title{
Pengaruh Model Pembelajaran Pakem Terhadap Prestasi Belajar Siswa SMPN 4 Batukliang
}

\author{
Hasanah \\ Pendidikan Matematika, Universitas Nahdlatul Wathan Mataram, Indonesia \\ hasanah@gmail.com
}

\section{ARTICLE INFO}

Article History:

Received : 05-09-2018

Revised : :14-11-2018

Accepted : :16-11-2018

Online : $: 26-11-2018$

Keywords:

Pengaruh; Pakem;

Prestasi Belajar

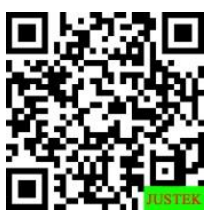

\begin{abstract}
Abstract: The purpose of this study was to determine the effect of pakem learning models on students' learning achievements in mathematics subjects, the subject matter of linear equations one variable in grade VII SMPN 4 Batukliang. This research uses a quantitative approach. The type of research used is Class Action Research (PTK). The population in this study was 190 students of SMPN 4 Batukliang. The instruments used in this research are about tests, observations and documentation. The analysis used is statistical data analysis with average different test using $t$-test. The results of the study obtained a score of $t_{-}$(calculate) of 7.59 , while the value of t_tabel of 2,000 with $d k=59$ and the level of significance of 0.05 this indicates that $\mathrm{Ho}$ was rejected and Ha was accepted so that it can be concluded that there is an influence of PAKEM learning model on student learning achievement in mathematics subjects linear equations one variable in grade VII SMPN 4 Batukliang
\end{abstract}

\begin{abstract}
Abstrak: Tujuan penelitian ini adalah untuk mengetahui pengaruh model pembelajaran PAKEM terhadap prestasi belajar siswa pada mata pelajaran matematika materi pokok persamaan linier satu variable di kelas VII SMPN 4 Batukliang. Penelitian ini menggunakan pendekatan kuantitatif. Adapun jenis penelitian yang digunakan adalah Penelitian Tindakan Kelas (PTK). Adapun populasi dalam penelitian ini yaitu siswa SMPN 4 Batukliang sebanyak 190 siswa. Adapun instrumen yang digunakan dalam penelitian ini adalah soal tes, observasi dan dokumentasi. Analisis yang digunakan adalah analisis data statistik dengan uji beda rata-rata menggunakan uji- t. Hasil penelitian diperoleh nilai $t_{\text {hitung }}$ sebesar 7,59 , sedangkan nilai $t_{\text {tabel }}$ sebesar 2,000 dengan $\mathrm{dk}=59$ dan taraf signifikansi 0,05 hal ini menunjukkan bahwa Ho ditolak dan Ha diterima sehingga dapat disimpulkan ada pengaruh model pembelajaran PAKEM terhadap prestasi belajar siswa pada mata pelajaran matematika materi pokok persamaan linier satu variabel di kelas VII SMPN 4 Batukliang
\end{abstract}

\section{A. LATAR BELAKANG}

Pendidikan merupakan suatu upaya yang paling efektif untuk meningkatkan kualitas sumber daya manusia (Muhardini et al. 2020)(Mahsup and Anwar 2020). Upaya peningkatan kualitas sumber daya manusia Indonesia sudah barang tentu dibutuhkan lembaga pendidikan formal seperti sekolah dari tingkat dasar sampai kejenjang perguruan tinggi (Kabunggul et al. 2020)(Adriyanto, Dewi Pramita, Abdillah, Syaharuddin, Mahsup 2019). Pendidikan merupakan unsur terpenting dalam upaya 
mendidik, membimbing dan merubah sikap dan prilaku seseorang termasuk peningkatan prestasi belajar peserta didik (M. Mahsup 2018)(Syaharuddin et al. 2020)(Mukminah, Eka Fitriani, Mahsup 2019)(M. Mahsup, Abdillah, and Mandailina 2019)(Mahsup, Abdillah 2018).

Prestasi belajar adalah suatu usaha yang telah dicapai oleh seorang anak didik setelah melakukan suatu kegiatan atau aktivitas pembelajaran dalam kurun waktu tertentu (Aribawati, Kristin, and ... 2018)(Rahmatin et al. 2019). Dengan demikian prestasi belajar merupakan suatu usaha yang dilakukan oleh seseorang atau peserta didik dalam proses belajar mengajar pada suatu bidang studi atau materi pelajaran tertentu (Mahsup and Anwar 2020)(Eka Fitriani 2018). Dengan kata lain prestasi belajar adalah hasil yang telah dicapai (diperoleh) oleh peserta didik setelah melakukan suatu aktivitas tertentu sebagai hasil dari proses intraksi dan aktualisasi dirinya baik dengan lingkungan sekolah, keluarga (orang tua) maupun lingkungan masyarakat sekitarnya (Arta Diantoro, Mahsup, and Pramita 2019)(M. Mahsup 2011). Upaya peningkatan prestasi belajar siswa melalui berbagai model pembelajaran termasuk model pembelajaran Pakem (pembelajaran aktif, kreatif, efektif dan menyenangkan) pada mata pelajaran matematika khususnya materi persamaan linier satu variabel sangat penting (Putra and Nasrullah 2017), sebab dengan model pembelajaran PAKEM ini siswa diharapkan lebih aktif, kreatif dan lebih siap dalam proses pembelajaran yang diakukan di dalam kelas. Oleh karena itu guru diiharapkan betul-betul menguasai model pembelajaran yang digunakan termasuk model pembelajaran PAKEM di dalam kelas (Astiti 2019)(Nurfiati, Vera Mandailina, Mahsup, Syaharuddin 2020).

Dalam pembelajaran PAKEM siswa juga dituntut terlibat secara aktif dalam proses pembelajaran (J. Jumairi 2018)(Puspita, Slameto, and ... 2018). Tidak hanya itu, guru juga dituntut untuk kreatif dalam menggunakan berbagai media belajar dan berbagai metode yang beragam (N. Jumairi 2019)(S. M. Mahsup 2018), situasi yang seperti itu di harapkan mampu untuk meningkatkan prestasi belajar siswa terutama pada pembelajaran matematika materi persamaan linier satu variabel. Adapun kelebihan dari PAKEM itu sendiri adalah : 1) dapat menggunakan sumber belajar yang beraneka ragam, yang kemudian didesain skenario pembelajarannya dengan berbagai kegiatan dan hasilnya itu bisa dipajang di tembok / di kelas. 2) kegiatan belajar mengajarnya bervariasi secara aktif yang biasanya didominasi oleh kegiatan individu. 3) dalam melaksanakan kegiatan, siswa dapat mengembangkan semaksimal mungkin kreativitasnya yang dalam hal ini tampaklah antusias serta rasa senang terhadap siswa (Suherman 2010)(Mahsup and Anwar 2020)(S. M. Mahsup 2018).

Dalam pembelajaran matematika di SMPN 4 Batukliang guru lebih banyak menggunaka metode ekspositori. Pembelajaran seperti ini tentunya berdampak pada aktivitas belajar siswa menjadi rendah yaitu seperti kurangnya antusias siswa untuk bertanya dan menyampaikan pendapat. Hal ini berakibat pada rendahnya prestasi belajar matematika siswa. Nilai rata-rata matematika siswa kelas VII untuk materi persamaan linier satu variabel di SMPN 4 Batukliang adalah untuk kelas VII ${ }^{\mathrm{A}}$ dengan nilai rata-rata 53,45 dan kelas $\mathrm{VII}^{\mathrm{B}}$ dengan nilai rata-rata 46,86. Berdasarkan tabel di atas, bahwa prestasi belajar matematika kelas VII masih rendah. Rendahnya hasil belajar yang di tunjukkan tentunya masih jauh dari yang diharapkan. Untuk itu sudah menjadi tugas guru dan calon guru untuk mengatasi hal tersebut. Berdasarkan uraianuraian tersebut, maka penulis tertarik untuk melakukan penelitian yang berjudul: "pengaruh model pembelajaran PAKEM terhadap prestasi belajar siswa pada mata pelajaran matematika materi pokok persamaan linier satu variable di kelas VII SMPN 4 Batukliang. 
Adapun tujuan penelitian ini adalah untuk mengetahui pengaruh model pembelajaran PAKEM terhadap prestasi belajar siswa pada mata pelajaran matematika materi pokok persamaan linier satu variable di kelas VII SMPN 4 Batukliang.

\section{B. METODE PENELITIAN}

Penelitian ini menggunakan pendekatan kuantitatif. Pendekatan kuantitatif digunakan karena data yang diperoleh dilapangan lebih memfokuskan kepada keterangan yang membutuhkan angka-angka (Sugiyono 2013)(Arikunto 2019). Adapun jenis penelitian yang digunakan adalah Penelitian Tindakan Kelas (PTK). P(Setyowati, Kristin, and Anugraheni 2018)opulasi dalam penelitian ini yaitu siswa SMPN 4 Batukliang sebanyak 190 siswa. Karena yang menjadi subyek penelitian ini adalah kelas VIIA dan VIIB. Instrumen yang digunakan dalam penelitian ini adalah soal tes, observasi dan dokumentasi. Analisis yang digunakan adalah analisis data statistik untuk uji beda rata-rata menggunakan uji- t.

\section{HASIL DAN PEMBAHASAN}

Hasil tes proses belajar mengajar matematika dengan metode pembelajaran PAKEM pada kelas eksperimen diperoleh nilai terendah yaitu 60 dan nilai tertinggi 90 dengan skor rata-rata 70,32. Sedangkan pada kelas kontrol diperoleh nilai terendah 40 dan nilai tertinggi 70 dengan skor rata-rata 54. Metode mengajar dalam proses pembelajaran memiliki peran penting dalam keberhasilan proses pembelajaran tersebut. Metode mengajar yang tepat dapat meningkatkan perhatian siswa terhadap materi pembelajaran serta melibatkan keaktifan siswa baik fisik maupun mental. Guru harus menggunakan metode yang bervariasi, tidak membosankan tetapi menarik perhatian anak didik. Jadi perhatian siswa dan keaktifan siswa merupakan faktor yang mempengaruhi prestasi belajar siswa.

Salah satu metode mengajar guru adalah model pembelajaran PAKEM. Dalam hal ini peneliti memberikan pertanyaan tentang materi persamaan linier satu variabel. Apabila pertanyaan-pertanyaan tersebut tidak dapat dijawab dengan benar maka guru (peneliti) berusaha untuk memberikan pertanyaan susulan yang dapat membimbing siswa untuk menemukan jawaban yang benar. Apabila ada pertanyaan-pertanyaan dari siswa maka guru (peneliti) tidak memberikan jawaban langsung, akan tetapi melemparkan kembali pertanyaan tersebut pada siswa yang lain sehingga keaktifan siswa sangat dituntut dalam model pembelajaran PAKEM ini. Dari data hasil penelitian diperoleh bahwa nilai ratarata (mean) untuk kelas eksperimen sebesar 70,32 dari 31 siswa sedangkan nilai rata-rata untuk kelas kontrol sebesar 54 dari 30 siswa. Dari data tersebut menunjukkan bahwa penerapan model PAKEM yaitu pada kelas eksperimen memperoleh nilai rata-rata lebih tinggi daripada nilai rata-rata kelas kontrol yang tidak menerapkan model pembelajaran PAKEM.

Selain itu juga terdapat nilai tengah (median) untuk setiap kelas yaitu kelas eksperimen mediannya sebesar 70 sedangkan kelas kontrol mediannya 50. Dari hasil nilai tengah (median) yang diperoleh menunjukkan bahwa pembelajaran dengan menerapkan model PAKEM nilai tengah siswa lebih tinggi daripada nilai tengah siswa yang pembelajarannya tidak menggunakan model PAKEM. Dilihat dari nilai modus bahwa kelas eksperimen modusnya sebesar 70 sedangkan kelas kontrol modusnya sebesar 50. Hal ini menunjukkan ada perbedaan antara kelas eksperimen dan kelas kontrol bahwa nilai modus kelas eksperimen lebih tinggi daripada kelas kontrol. Dari hasil analisis data juga diperoleh nilai $t_{\text {hitung }}$ sebesar 7,59 sedangkan nilai $t_{\text {tabel }}$ dengan

$\mathrm{dk}=59$ sebesar 2,000. Setelah $t_{\text {hitung }}$ dikonsultasikan dengan $t_{\text {tabel }}$ dengan taraf signifikansi 0,05 sehingga dapat dilihat bahwa $t_{\text {hitung }}>t_{\text {tabel }}$. Oleh karena $t_{\text {hitung }}>t_{\text {tabel }}$ 
maka hipotesis yang diajukan diterima yaitu "Ada pengaruh model pembelajaran PAKEM terhadap prestasi belajar siswa pada mata pelajaran matematika materi pokok persamaan linier satu variabel di kelas VII SMPN 4 Batukliang.

\section{SIMPULAN DAN SARAN}

Berdasarkan hasil analisis penelitian ini, maka diperoleh nilai $t_{\text {hitung }}$ sebesar 7,59, sedangkan nilai $t_{\text {tabel }}$ sebesar 2,000 dengan $\mathrm{dk}=59$ dan taraf signifikansi 0,05 hal ini menunjukkan bahwa Ho ditolak dan Ha diterima sehingga dapat disimpulkan ada pengaruh model pembelajaran PAKEM terhadap prestasi belajar siswa pada mata pelajaran matematika materi pokok persamaan linier satu variabel di kelas VII SMPN 4 Batukliang. Adapun saran dalam penelitian ini yaitu (1) agar guru hendaknya dalam mengajar menggunakan metode yang bervariasi dan tepat; (2) siswa untuk lebih aktif dalam menuntut ilmu dan meningkatkan prestasi belajarnya khususnya pada mata pelajaran matematika.

\section{UCAPAN TERIMA KASIH}

Ucapan terima kasih kepada guru dan kepala sekolah SMPN 4 Batukliang yang telah yang sudah memberikan kontribusi selama penelitian dilaksanakan.

\section{REFERENSI}

Adriyanto, Dewi Pramita, Abdillah, Syaharuddin, Mahsup, Eka Fitriani. 2019. "Peningkatan Kompetensi Strategis Siswa Melalui Model Pembelajaran Conceptual Understanding Procedures." Justek: Jurnal Sains dan Teknologi 2(1): 01-10. http://journal.ummat.ac.id/index.php/justek/article/view/3535/pdf.

Aribawati, D, F Kristin, and ... 2018. "Penerapan Model Pembelajaran Inkuiri Terbimbing Untuk Meningkatkan Kreativitas Dan Hasil Belajar Ipa Siswa Kelas 3 SD.” Justek/ Jurnal Sains \& ....

Arikunto. 2019. "Metodelogi Penelitian, Suatu Pengantar Pendidikan." In Rineka Cipta, Jakarta, , 21.

Arta Diantoro, Syaiful Barsa, Mahsup Mahsup, and Dewi Pramita. 2019. "Penerapan Model Pembelajaran Kooperatif Tipe Two Stay Two Stray (TSTS) Dalam Meningkatkan Hasil Belajar Bentuk Aljabar Siswa Kelas VII SMP." Paedagoria / FKIP UMMat 10(1): 01.

Astiti, N M A. 2019. "Penerapan Metode Problem Based Learning Dalam Menciptakan Suasana PAKEM Untuk Meningkatkan Prestasi Belajar Pendidikan Agama Hindu Dan Budi Pekerti." Kamaya: Jurnal Ilmu Agama.

Eka Fitriani, Mahsup. 2018. "Pengaruh Pembelajaran Kooperatif Tipe Jigsaw Untuk Meningkatkan Pemahaman." Justek: Jurnal Sains dan Teknologi 1(2): 01-08. http://journal.ummat.ac.id/index.php/justek/article/view/3541.

Jumairi, J. 2018. "Meningkatkan Kemampuan Mengapresiasi Dongeng Melalui Metode Pakem Siswa Kelas VIII-C SMP Negeri 5 Tenggarong." Intelegensia: Jurnal Pendidikan dan Pembelajaran.

Jumairi, NFN. 2019. "Peningkatan Hasil Belajar Menulis Cerita Fantasi Dengan Menggunakan Metode Pakem Siswa Kelas VIII-C SMP Negeri 5 Tenggarong Tahun Pelajaran 2018/2019." LOA: Jurnal Ketatabahasaan dan Kesusastraan 14(1): 21.

Kabunggul, Yosua et al. 2020. "Meningkatkan Motivasi Dan Hasil Belajar Siswa Melalui Penerapan Model Pembelajaran Team Game Tournament Berbantuan Media ...." Jurnal Pendidikan Karakter 3(2): 3-6. 
Mahsup, and Y. S. Anwar. 2020. "Development of Structured Modules to Improve the Mathematical Understanding of the Circle Concept in Class VIII Mataram 17 Junior High School." In Journal of Physics: Conference Series,.

Mahsup, Abdillah, Syaharuddin. 2018. "Peningkatan Penguasaan Konsep Lingkaran Dengan Metode Penemuan Bagi Mahasiswa." Paedagoria 9(2): 91-96. http://journal.ummat.ac.id/index.php/paedagoria/article/view/871.

Mahsup, Mahsup. 2011. "Penerapan Stategi Inquiri Untuk Meningkatkan Hasil Belajar Tentang Sistem Persamaan Linear Dua Variabel.” Beta 4(2): 120-32. file://C:/Users/Mahsup/Downloads/document (1).pdf.

-_- 2018. "Analisis Kesulitan Dalam Memahami Kemampuan Verbal Dalam Membuat Model Matematika Program Linear." Jurnal Ulul Albab 22(2).

Mahsup, Mahsup, Abdillah Abdillah, and Vera Mandailina. 2019. "Tri Out Ujian Nasional Dan Pembahasanya Pada Soal Matematika Siswa Kelas IX MTS Daarusy Syifaa Tirtanadi Lombok Timur." JMM (Jurnal Masyarakat Mandiri) 3(1): 12.

Mahsup, Sintayana Muhardini. 2018. "Pengaruh Model Pembelajaran Snowball Throwing Untuk Meningkatkan Hasil Belajar Matematika Siswa SMPN 21 Mataram." Prosiding Seminar Nasional Pendidik dan Pengembang Pendidikan Indonesia: 301-9.

Muhardini, Sintayana et al. 2020. "Pengembangan Media Pembelajaran Box Nusantara Untuk Membentuk Kemampuan Memahami Konsep Tematik Pada Siswa Sekolah Dasar." Jurnal Kependidikan: Jurnal Hasil Penelitian dan Kajian Kepustakaan di Bidang Pendidikan, Pengajaran dan Pembelajaran 6(2): 284.

Mukminah, Eka Fitriani, Mahsup, Syaharuddin. 2019. "Efektifitas Model Pembelajaran Kooperatif Tipe Teams Games Tournament Untuk Meningkatkan Hasil Belajar." Justek: Jurnal Sains dan Teknologi 2(2): 1-5. http://journal.ummat.ac.id/index.php/justek/article/view/3533.

Nurfiati, Vera Mandailina, Mahsup, Syaharuddin, Abdillah. 2020. "Effect of Make A Match Learning Model on Student Learning Outcomes on Statistical Materials." Justek: Jurnal Sains dan Teknologi 3(1): http://journal.ummat.ac.id/index.php/justek/article/view/3509.

Puspita, M, S Slameto, and ... 2018. "Peningkatkan Hasil Belajar Matematika Siswa Kelas 4 Sd Melalui Model Pembelajaran Problem Based Learning.” Justek/ Jurnal Sains \& ....

Putra, Hermanus Iwan, and Anton Nasrullah. 2017. "Implementasi Pendekatan Pembelajaran Aktif, Kreatif, Efektif Dan Menyenangkan Ditinjau Dari Hasil Belajar.” Union: Jurnal Ilmiah Pendidikan Matematika 5(2): 131.

Rahmatin, Nutia, Dewi Pramita, Sirajuddin Sirajuddin, and Mahsup Mahsup. 2019. "Pengembangan Modul Pembelajaran Bangun Ruang Dengan Metode Creative Problem Solving (CPS) Pada Siswa Kelas VIII SMP.” JTAM / Jurnal Teori dan Aplikasi Matematika 3(1): 27.

Setyowati, Endah, Firosalia Kristin, and Indri Anugraheni. 2018. "Penggunaan Model Pembelajaran Discovery Learning Untuk Meningkatkan Kreativitas Dan Hasil Belajar Siswa Kelas 5 SD Negeri Mangunsari 07." JUSTEK/ Jurnal Sains \& Teknologi 1(1): 76-81.

Sugiyono. 2013. “Buku - Sugiyono.” In Metode Penelitian Kuantitatif, Kualitatif, Dan R \& $D, 407$.

Suherman, Ayi. 2010. “Model Pembelajaran Pakem Dalam Pendidikan.” Jurnal Penelitian Pendidikan 11(1): 131-41.

Syaharuddin, Syaharuddin et al. 2020. "Penelusuran Referensi Berbasis Digital Sebagai Peningkatan Soft Skill Mahasiswa Dalam Menyelesaikan Tugas Akhir." Selaparang Jurnal Pengabdian Masyarakat Berkemajuan 3(2): 151. 